\title{
Laboratory findings in imaging diagnostic tests in patients infected with COVID-19 - A study review
}

\author{
Achados laboratoriais em exames de imagem em pacientes diagnosticados com COVID-19 - Uma \\ revisão de estudo
}

Hallazgos de laboratorio en exámenes de imágenes en pacientes diagnosticados con COVID-19 -

Revisión de estudio

Caio Robert Rodrigues Martins De Souza ORCID: https://orcid.org/0000-0003-3142-2460

Tiradentes University, Brazil

E-mail: c.g.e100@hotmail.com

Danilo Lopes Santos

ORCID: https://orcid.org/0000-0001-9944-2682

Tiradentes University, Brazi

E-mail: santosdanilo518@gmail.com

Larissa Maria Freire de Melo

ORCID: https://orcid.org/0000-0003-2803-0845

Estácio Sergipe University Center, Brazil

E-mail: larissamfmelo@gmail.com

Lumar Lucena Alves

ORCID: https://orcid.org/0000-0002-0375-1286

Gerald Champion Regional Medical Center, USA

E-mail: lumarlucena2@yahoo.com.au

Luiz André Santos Silva

ORCID: https://orcid.org/0000-0003-1607-8649

Federal University of Sergipe, Brazil

E-mail: luizandressilva@yahoo.com.br

Natália Jamille Alves de Santana

ORCID: https://orcid.org/0000-0002-0125-7591

Tiradentes University, Brazil

E-mail: alvessnat@outlook.com

Míriam Clécia de Oliveira Santos

ORCID: https://orcid.org/0000-0001-6613-267X

Tiradentes University, Brazil

E-mail: miriam.clecia@hotmail.com

Thatyane Gama Carvalho

ORCID: https://orcid.org/0000-0001-6321-1655 Tiradentes University, Brazil

E-mail: thatyanegaamac@gmail.com

Jonas Prata Estevão dos Santos ORCID: https://orcid.org/0000-0002-3332-0428 Tiradentes University, Brazil

E-mail: jonasprata.radiologia@gmail.com

Tereza Tizar Alves Oliveira ORCID: https://orcid.org/0000-0002-6010-0703 Tiradentes University, Brazil E-mail: tizarxp@gmail.com

Ingridy Evangelista Viana Lucena ORCID: https://orcid.org/0000-0002-0709-9969 Tiradentes University, Brazil

E-mail: ivlbiomedica@gmail.com

Raphaella Ingrid Santana Oliveira ORCID: https://orcid.org/0000-0002-7027-9049

Estácio Sergipe University Center, Brazil E-mail: dr.raphaella@gmail.com

\footnotetext{
Abstract

Purpose: This study disseminates the diagnosis of COVID-19 emphasizing the importance of imaging tests in medical interpretation and identification of its complications, besides demonstrating the contribution to patient care.
} 
Methodology: The study was conducted based on a literature review, in addition to the acquired results of imaging tests from clinical patients at a Public Hospital of the State of Sergipe, Brazil, to point the scoring system in thorax radiography and compare to computed tomography (CT). Results: The imaging tests are not indicated for patients with mild symptoms and suspected COVID-19 infection, except for risk of disease progression, being indicated in the complementary diagnosis of COVID-19 positive patients. Studies show that thorax radiography is more used because it has low cost and easy access. However, its use has limitations due to the low sharpness of the images and impossibility of visualization of some lesions. Computed tomography, on the other hand, can be used as a pulmonary monitoring and evolution test in patients with COVID-19 worsening and/or persistent homeostatic changes. Nevertheless, this test is not indicated for acute cases without aggravating symptoms. Conclusion: The high degree of dissemination of SARS-CoV-2 and the collapse of health systems demonstrated the importance of the science in health. In addition, the importance of laboratory tests in the diagnosis of virus infection and imaging tests in the early diagnosis of SARS-CoV-2 pneumonia has been shown as efficient complementarity in the evolution and clinical interpretation of patients, highlighting the importance of radiography and CT exams.

Keywords: COVID-19; Medical imaging; Computed tomography; X-ray; Thorax radiography.

\section{Resumo}

Objetivo: Destacar o diagnóstico de COVID-19 enfatizando a importância dos exames de imagem na interpretação médica e na identificação de suas complicações, além de demonstrar a contribuição para o cuidado do paciente. Metodologia: Estudo baseado em uma revisão da literatura e exames de imagem de pacientes clínicos de um Hospital Público do Estado de Sergipe, Brasil, para apontar o sistema de pontuação em radiografia de tórax e comparar com a tomografia computadorizada (TC). Resultados: Os exames de imagem não são indicados para pacientes com sintomas leves e suspeita de infecção por COVID-19. Portando, eles sendo indicados no diagnóstico complementar de pacientes COVID-19 positivos. Estudos mostram que a radiografia de tórax é mais utilizada por ter baixo custo e fácil acesso. Porém, seu uso apresenta limitações devido à baixa nitidez das imagens e impossibilidade de visualização de algumas lesões. A tomografia computadorizada, por outro lado, pode ser utilizada como monitoramento pulmonar e teste de evolução em pacientes com piora do COVID-19 e / ou alterações homeostáticas persistentes. No entanto, este teste não é indicado para casos agudos sem sintomas agravantes. Conclusão: O alto grau de disseminação do SARS-CoV-2 e o colapso dos sistemas de saúde demonstram a importância da ciência em saúde. Além disso, a importância dos exames laboratoriais no diagnóstico da infecção viral e dos exames de imagem no diagnóstico precoce da pneumonia por SARS-CoV-2 tem se mostrado como uma complementaridade eficaz na evolução e interpretação clínica dos pacientes, destacando-se a importância dos exames de radiografia e tomografia computadorizada.

Palavras-chave: COVID-19; Exames de imagem; Tomografia computadorizada; Raio-X; Radiografia de tórax.

\section{Resumen}

Objetivo: Este estudio disemina el diagnóstico de COVID-19 enfatizando la importancia de los exámenes de imagen en la interpretación y en la identificación de sus complicaciones, además de contribuir para el cuidado del paciente. Metodología: El estudio tuvo base en la literatura y en los resultados de exámenes de imagen de pacientes de un Hospital Público de Sergipe, Brasil, para señalar el sistema de puntuación en radiografía de tórax y comparar con la tomografía computarizada (TC). Resultados: Exámenes de imagen no están indicados para pacientes con síntomas leves y sospecha de infección por COVID-19, excepto con riesgo de progresión de la enfermedad. Por Consiguiente, se indican en el diagnóstico complementario de pacientes COVID-19 positivos. Estudios muestran que utilizan la radiografía de tórax por tener bajo costo y fácil acceso. Pero, su uso presenta limitaciones debido a la baja nitidez de las imágenes e imposibilidad de visualizar algunas lesiones. En contraste, puede utilizar la tomografía computarizada como monitoreo pulmonar y prueba de evolución en pacientes con empeoramiento del COVID-19 y/o alteraciones homeostáticas persistentes. Sin embargo, no está indicada para casos agudos sin síntomas agravantes. Conclusión: El alto grado de diseminación del SARS-CoV-2 y el colapso de los sistemas de salud demuestran la importancia de la ciencia en salud. Además, los exámenes de laboratorio en el diagnóstico de la infección vírica y las imágenes para el diagnóstico precoz de la neumonía por SARS-COV-2 demostró ser complemento eficaz en la evolución e interpretación clínica, destacando la importancia de radiografía y tomografía computarizada.

Palabras clave: COVID-19; Exámenes de imagen; Tomografía computarizada; Rayos X; Radiografía del tórax.

\section{Introduction}

The disease provoked by the new coronavirus (COVID-19) is currently a public health emergency of global importance, which is caused by SARS-CoV-2, a single-stranded enveloped RNA virus belonging to the Coronaviridae family (Casanova et al, 2020; Huang et al, 2020a; Wu et al, 2020). Presently, there are 7 coronaviruses identified with human tropism, between these the MERS-CoV, SARS-CoV-1, and SARS-CoV-2 are the most hazardous for humans. Following right after the rhinoviruses, the coronaviruses are the most frequent cause of common colds. However, the SARS-CoV-2 infection gains 
worldwide proportion for it is an unknown pathogen, so there are still no drugs developed for the treatment of COVID- 19 (Casanova et al, 2020; Huang et al, 2020a; Wu et al, 2020).

SARS-CoV-2, which had its first case reported in the city of Wuhan in China, has infected millions of people worldwide (Barone et al, 2020; Casanova et al, 2020; Chen Et Al, 2020; Vardavas \& Nikitara, 2020; World Health Organization, 2020; Zhou Et Al, 2020). The American continent currently has the highest number of infected people. Further, two countries of that continent occupy the world ranking of confirmed cases of the disease, with the first place occupied by the United States $(32,257,416)$, followed India $(21,892,676)$ and Brazil $(15,003,563)$ (WHO, 2020). This increase has exceeded the capacity of health systems, overcrowding units, and consequently leading to the collapse of the health system in many countries (Peck, 2020). This result was a consequence of the deficit of prevention methods, business and educational institutions re-opening, shifting from outdoors to indoors gathering, misinformation campaigns, among other factors which contributed to the increase in number of infected individuals in these regions.

The techniques currently available for diagnosis are molecular assays, such as reverse-transcriptase polymerase chain reaction (RT-PCR) (Araujo-Filho et al, 2020; Neto et al, 2021), and immunological tests such as Enzyme-Linked Immunosorbent Assay (ELISA) (Zheng et al, 2020). Moreover, there are also imaging tests, which are of great contribution to the diagnosis of disease complications, such as pneumonia and neurological disorders. On top of that, such tests are relevant for monitoring patients with these complications, as they assist in clinical decision-making and assessment of treatment effectiveness (Araujo-Filho et al, 2020; Huang et al, 2020a). Alongside, Huang et al (2020b) reported the importance of imaging tests for the diagnosis of false-negative patients for covid-19 in laboratory tests. Thus, this current study discloses the diagnosis of COVID-19 emphasizing the importance of imaging tests in medical interpretation and identification of disease's complications, besides demonstrating how these findings contribute to patient care.

\section{Methodology}

This study was performed based on a qualitative literature review from electronic sources to report the number of COVID-19 cases worldwide and highlight the relevance of imaging tests to aid in the diagnostic of individuals infected by SARS-Cov-2. The method included the evaluation of the studies from several authors, through a review regarding COVID-19 to develop significant conclusions concerning the subject under study. The methodology allowed to describe and cite the contributions of the authors regarding the results of imaging tests, addressing clinical interpretation and identification of complications of the disease.

\subsection{Search strategy}

The search for scientific articles was based on articles published during the pandemic period from April 2020 to April 2021 in the respective databases PubMed, Science Direct and Scielo. In this research the following descriptors were applied: coronavirus, COVID-19, SARS-CoV-2, thorax radiography, computed tomography and imaging tests. Furthermore, imaging tests results from clinical patients were acquired from Public Hospital of State of Sergipe, Brazil to demonstrate the application of the scoring system in thorax radiography (CXR Score), as well as imaging tests of thorax computed tomography (CT) from Emergency Hospital of Sergipe (HUSE), Brazil, were analyzed and compared.

\section{Results and Discussion}

The authors Prado and Barjud (2020) point out a structure for the use of imaging tests, with the use of these tests not being indicated in patients with suspected COVID-19 with mild symptoms, except cases at risk of disease progression. 
The cases indicated for the use of the image diagnostic as a complementary exam in the diagnosis are of patients positive for COVID-19 and with the decline of the respiratory state; patients with negative tests for COVID-19, but with indicative symptoms; patients with suspected COVID-19 with moderate to severe clinical characteristics and with a high probability of progression of the pathology (Rubin et al, 2017).

One of the most requested exams in the world is thorax radiography, an imaging method with low cost, great availability, and low radiation dose with ionization dose with frontal and lateral views of approximately $0.015 \mathrm{mSv}$ (Chate, 2003). Thorax radiography is used as a first-line diagnosis, due to its easy access and low cost. However, the resolution of the image, together with the difficulty in identifying certain lesions, makes it an exam with an unreliable radiological diagnosis. Computed tomography is an exam with high image quality and provides an easy diagnosis, although it presents limited specificity and a high dose of radiation in comparison with thorax X-ray (Gordon et al, 2020).

Computed tomography (CT) can be used as an exam for monitoring and pulmonary evolution in patients who have worsened COVID-19 and/or persistent homeostatic changes. Therefore, this test is not indicated for acute cases without aggravating symptoms (Foust et al, 2020). Although CT can provide a wealth of details and high-resolution images in about 5 seconds, it has a high degree of ionization. In helical CT scan, the radiation level is approximately $10 \mathrm{mSv}$ and in thorax CT with low radiation dose it is still up to 3 times higher than thorax radiography (Baroni, 2003; Chate, 2003).

At the beginning of the symptoms, it is common not to show changes on the thorax X-ray, which may confuse the diagnosis with other pulmonary pathologies (Souza et al, 2002). In the early stage of the disease, the most common CT findings are focal opacities or consolidation, bilateral multifocal airspace, and lesions with peripheral distribution. Opacity is characterized by an image with greater attenuation in X-ray beams than in adjacent structures (Shi et al, 2020; Souza et al, 2002).

Opacities are shown in ground-glass opacity (GGO) and consolidation. GGO consists of an increase in the parenchyma attenuation coefficient, with preservation of bronchovascular marks. In the case of consolidation, a homogeneous increase in attenuation of the pulmonary parenchyma is characteristic, obscuring the margins of the vessels and the walls of the airways. Air space is considered the gas contained in the lung parenchyma with the inclusion of acids (Santos et al, 2003; Souza et al, 2002).

According to Prado and Bajurd (2020), there may be indeterminacy in the diagnosis of COVID-19, since the lung in the normal state may present opacities with attenuation in ground glass related to hypoperfusion and hypoventilation, indicating the consideration of the analysis of the patent of the pulmonary vasculature. Furthermore, GGO can be nonspecific, causing chills between infections, such as H1N1, influenza, MERS and SARS (Prado \& Bajurd, 2020).

The emergence of consolidation, reticular opacities, bilateral involvement, and peripheral distribution is typical of the intermediate phase of COVID-19 (Shi et al, 2020). Reticular opacities denote the thickening of the connective tissue chain, and it occurs mainly by the thickening of the interlobular septa (Elicker et al, 2008).

The thorax X-ray in the middle period of COVID-19 may present opacities in multifocal air spaces. Air space refers to the gas within the lung parenchyma, where gas exchange in the respiratory system takes place (Souza et al, 2002). The thorax X-ray is not sensitive to mild and moderate infections, and in some cases, the thorax X-ray does not efficiently translate the affected lung component. In the cases of patients undergoing X-ray examination in the early form of the disease, the result does not have sufficient outpatient value to be considered as a conduct definer (Prado \& Bajurd, 2020).

In the current reality, thorax radiography is used as a first-line radiological diagnosis in suspected and confirmed cases of COVID-19, besides exhibiting little sensitivity in identifying initial manifestations of the disease. However, through radiography it is possible to identify consolidations, a criterion of the severity of the pathology, although it is not specific to COVID-19, this finding is common in this disease (Estevão, 2020). Thorax CT has high sensitivity but has little specificity. 
The test can be used to support the decision on hospitalization between the common ward and the ICU (Intensive Care Unit), as well as in patients with pre-existing diseases (Organização Pan-Americana De Saúde/OMS, 2020). Computed tomography should be considered in positive patients from COVID-19, hospitalized, and symptomatic with the possibility of clinical worsening. Imaging exams alone are not able to diagnose COVID-19 (OPAS/OMS, 2020).

\subsection{Thorax radiography}

Thorax radiography has little sensitivity for the diagnosis of COVID-19 (>69\%). Also, there may be misunderstanding in its analysis with suggestive symptoms of underlying comorbidities, such as heart failure and chronic lung disease (Toussie et al, 2020). However, through accurate, consistent, and predictive interpretations, it is considered the main imaging modality used in screening diagnosis, and clinical treatment, as it presents variable results able to predict pulmonary pathology. This test has a better diagnosis in people under the age of 50 years (Prado \&Bajurd, 2020; Toussie et al, 2020).

A survey conducted with 100 patients, adapted a scoring system already used in thorax radiography for respiratory infections, for patients affected by the infection caused by SARS-CoV-2 (confirmed by the RT-PCR test) (Borghesi \& Maroldi, 2020). The study consists of two stages of analysis, the first stage is characterized by the division of the lung into 6 zones in the frontal projection of the thorax, as represented in Figure 1.

Figure 1. Thorax radiography in anteroposterior (AP) position on a patient's bed in a public hospital in Sergipe, Brazil, showing the division of the lung into 6 zones (A, B, C, D, E and F). This division is used for analysis and application of the scoring system proposed by Borghesi and Maroldi (2020) on thorax radiography.

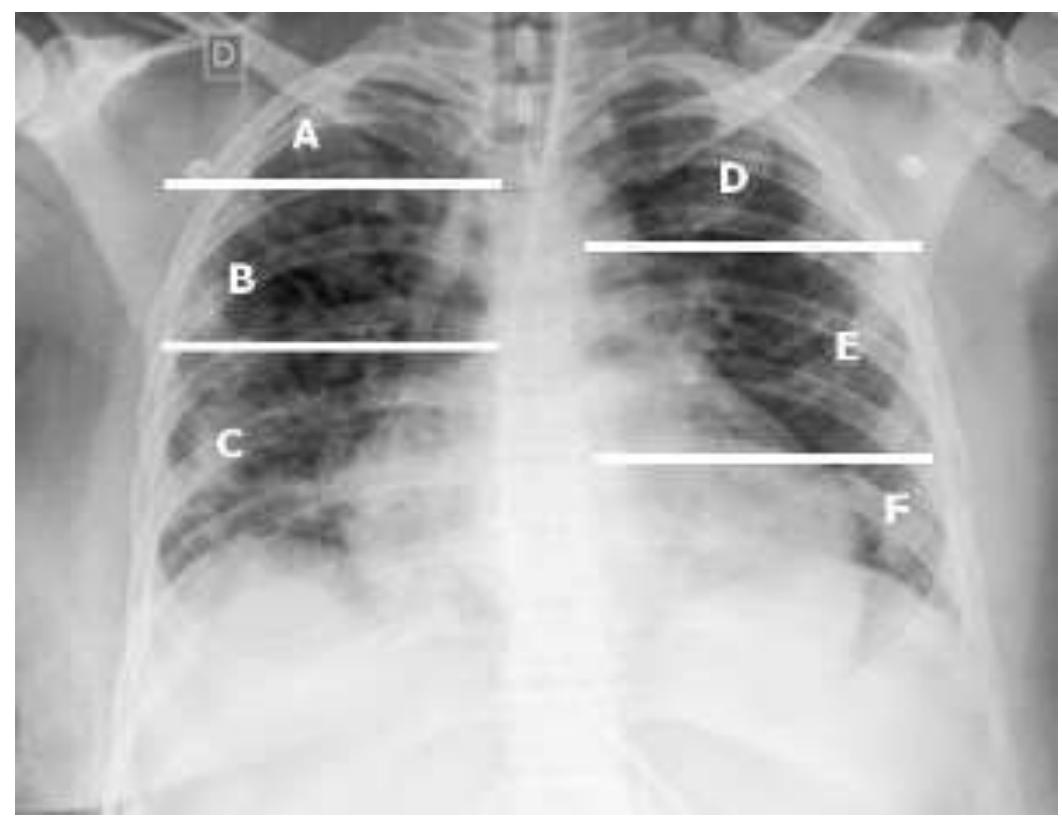

Source: Own source.

The division of the lung into 6 zones has the following characteristics: upper zones, above the lower wall of the aortic arch (A and D); medium zones, below the lower wall of the aortic arch and above the lower wall on the lower right side of the pulmonary vein, the hilar structures (B and E); inferior zones, below the inferior wall of the right inferior pulmonary vein, the pulmonary bases (C and F). This knowledge allows the mentioned study to move to the second phase (Borghesi \& Maroldi, 2020). 
In the second phase, points were assigned (0-3) to each zone according to the pulmonary abnormalities found, called CXR Score in the study. Score 0, without pulmonary abnormalities; score 1, presentation of interstitial infiltrates; score 2, presentation of interstitial and alveolar infiltrates, with a predominance of interstitials; score 3, presentation of interstitial and alveolar infiltrates, with a predominance of alveolar cells. The patients with the highest scores were those who had complications that led to death $(\mathrm{p} \leq 0.002)$ (Borghesi \& Maroldi, 2020).

The images below (Figures 2, 3, and 4) were taken in a public hospital in the State of Sergipe, Brazil, and demonstrates the application of the scoring system in thorax radiography proposed by Borghesi and Maroldi (Borghesi \& Maroldi, 2020), the CXR Score, in its analysis.

Figure 2. Female patient, 47 years old. Presence of nasogastric tube with guide wire and orotracheal tube. AP radiography performed on the bed showing bilateral diffuse irregular opacities, most prominent in the peripheral, inferior and hilar regions. CXR score: 8 [112112].

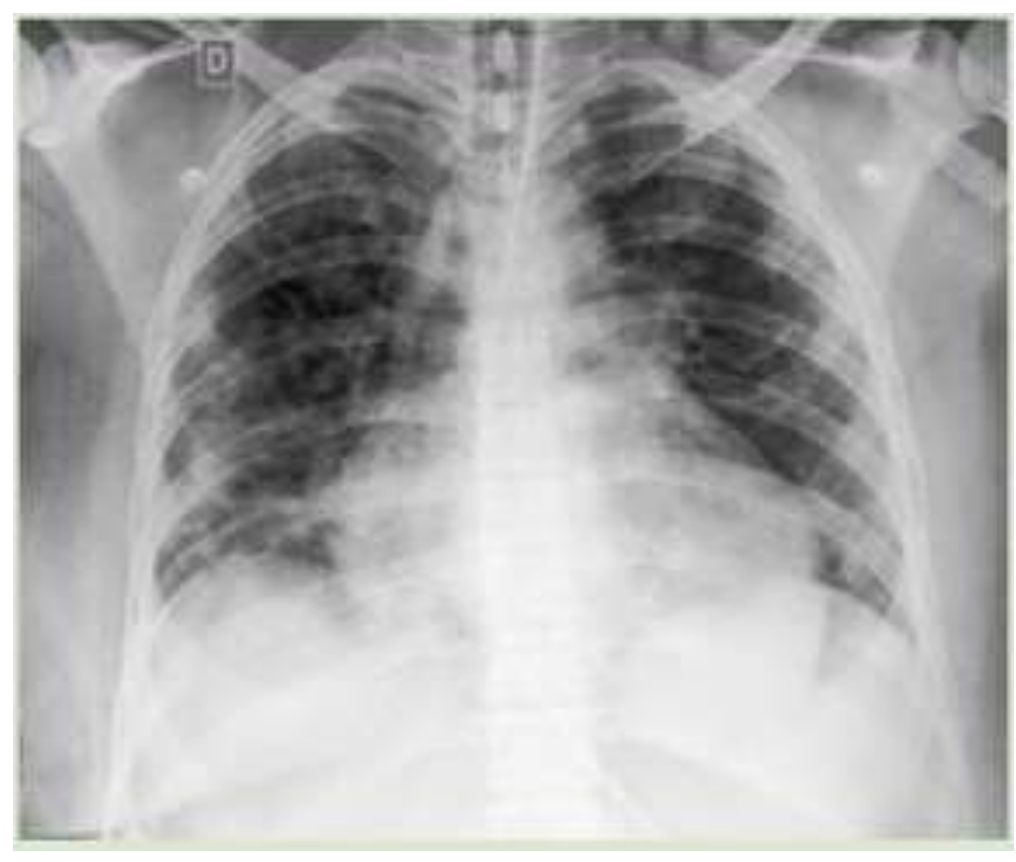

Source: Own source. 
Figure 3. Female patient, 61 years old, obese. Radiography performed in bed AP showing bilateral diffuse irregular opacities. CXR Score: 13 [222232].

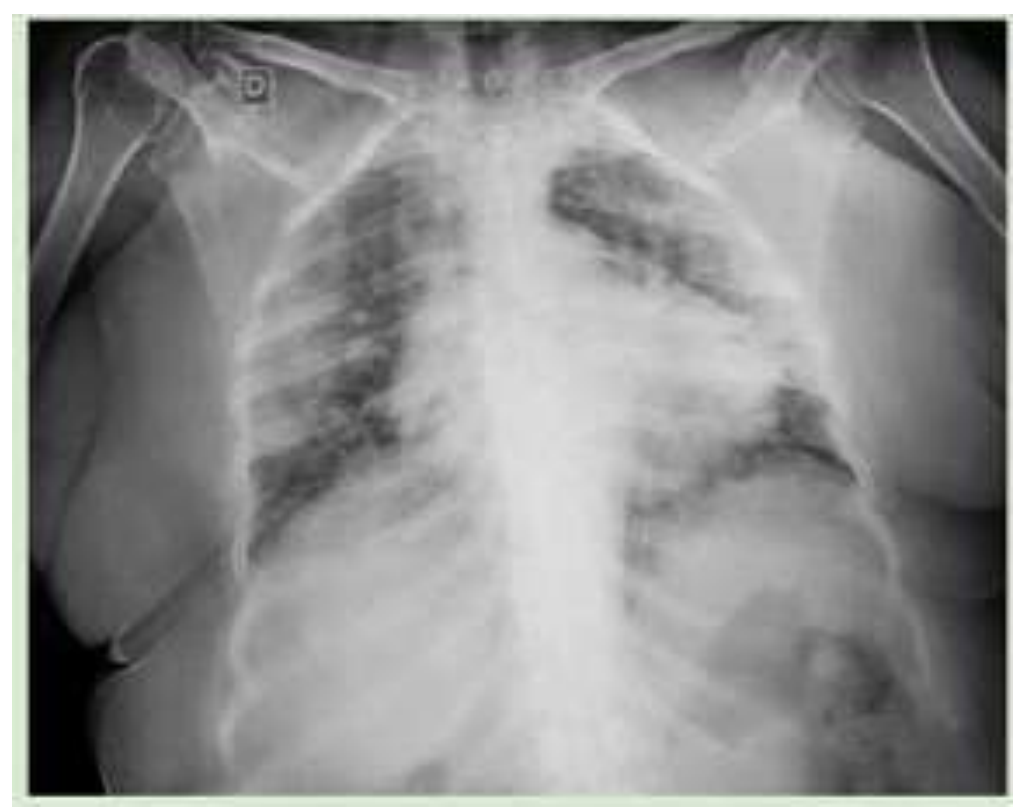

Source: Own source.

Figure 4. Male patient, 66 years old. Presence of orotracheal tube and central venous access. Radiography performed in AP on bed showing bilateral diffuse irregular opacities. CXR Score: 13 [222223].

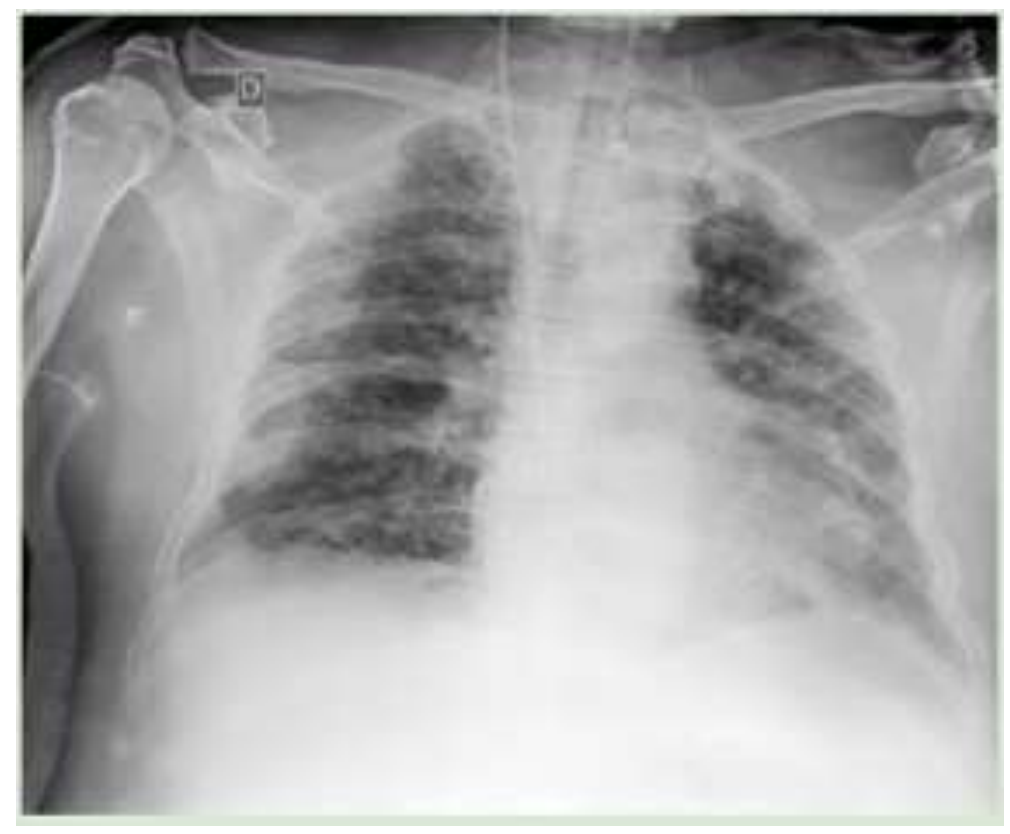

Source: Own source.

In the figures above, cases with the CXR Score showing the lowest score (Figure 2) and two distinct cases showing the same score (Figures 3 and 4) were shown. Another retrospective study was performed in March 2020 with 783 patients (532 men and 251 women) in Italy who contracted the disease and tested positive using the RT-PCR method (Borghesi \& Maroldi, 2020b). This research has men and women aged between 20 and 80 years as main subjects. It was verified through 
thorax radiography that patients who had greater involvement due to COVID-19 are patients who had a previous pathology, the most serious being: hypertension, diabetes, heart disease, cancer, and advanced age (Borghesi \& Maroldi, 2020b). Through the analysis it was noticed that the evolution to severe lung disease is more common in men over the age of 50 years and women over the age of 80 years, and the worsening at younger ages is not ruled out (Borghesi \& Maroldi, 2020b).

The radiographs have as positive advantages the greater availability in the places, fast execution, low cost and less exposure to ionizing radiation in comparison to computed tomography (CT). It is an essential tool in the diagnosis, monitoring and evaluation of the effectiveness of treatment for pneumonia caused by COVID-19. However, they can present false negatives due to the low sensitivity of detecting changes in cases of initial evolution of the affections (Cellina et al, 2020).

\subsection{Computed Tomography (CT)}

Thorax CT can contribute positively to the clinical diagnosis. The characterization, assessment of severity, and the detection of lesions, including early ones, which are rarely seen on the radiograph, can facilitate clinical classification and assist in the decision on the best possible treatment (Wang et al, 2020). The combined use of imaging tests with clinical laboratory data can provide an early diagnosis of COVID-19 pneumonia (Shi et al, 2020). In patients with pneumonia, the findings may demonstrate different patterns varying according to the course of the disease (Shi et al, 2020). There may be changes in the tomographic examination according to the patient's age, immune status, underlying diseases, and use of drug interventions (Wu et al, 2020). The images below (Figures 5 and 6) were taken at Emergency Hospital of Sergipe (HUSE), Brazil.

Figure 5. Male patient, 60 years old, with a positive result for COVID-19. Examination performed 8 days after the onset of symptoms. Axial sections obtained through thorax CT detecting mild changes. These lesions were not seen on radiography.
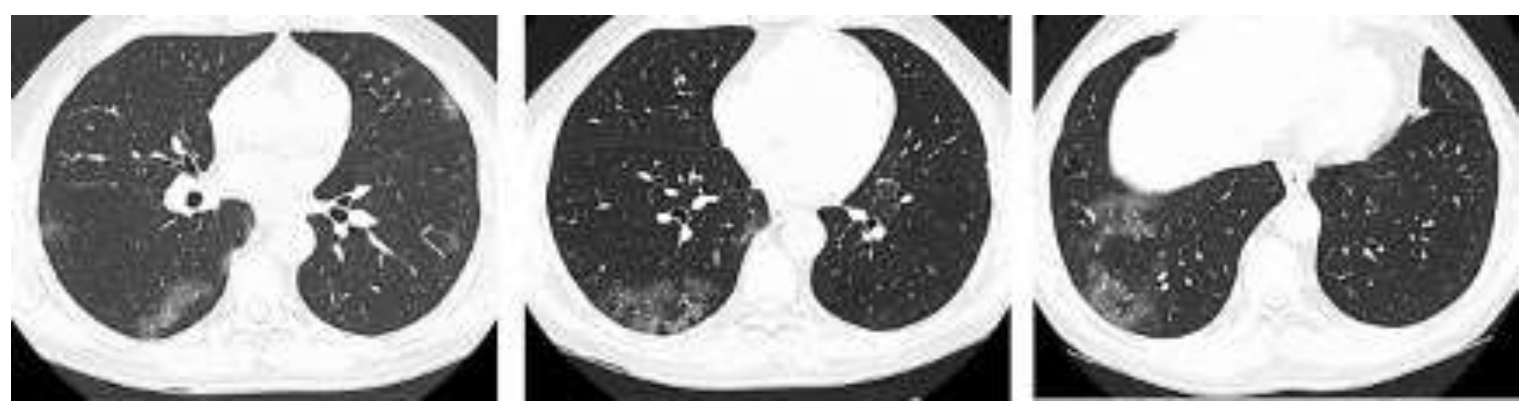

Source: Own source. 
Figure 6. Male patient, 67 years old, with a positive result for COVID-19. Examination performed approximately 14 days after the onset of symptoms. Axial sections obtained through thorax CT, showing changes in the lung parenchyma in an advanced stage with ground-glass attenuation affecting both lungs.
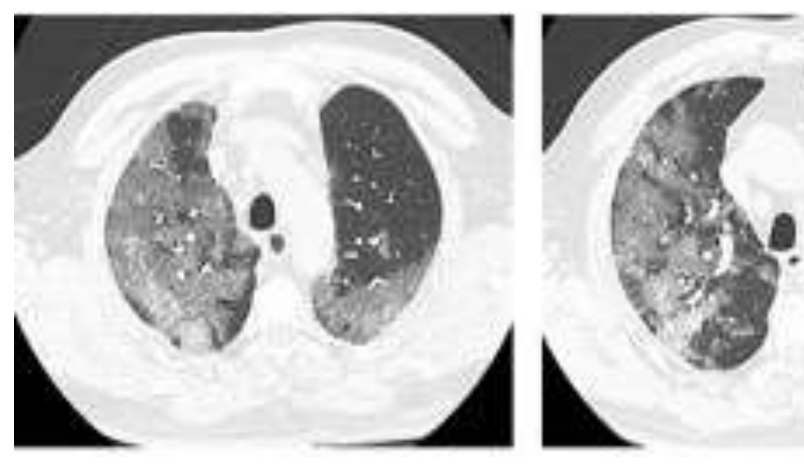
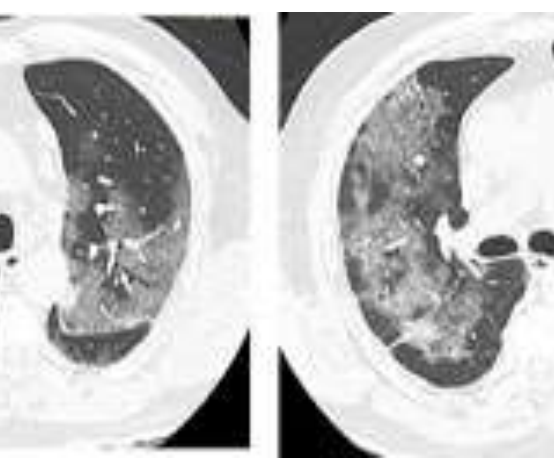

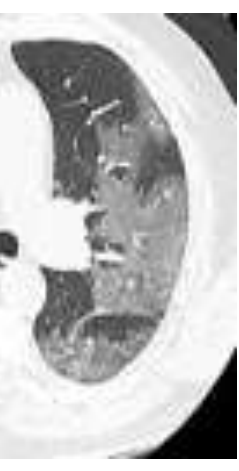

Source: Own source.

In a study with 81 patients, Shi et al (2020) found ground-glass opacity (65\%), ill-defined margins (81\%), smooth or irregular interlobular septal thickening (35\%), air bronchogram (47\%), crazy paving pattern (10\%) and thickening of the adjacent pleura (32\%). Other less common findings mentioned were nodules $(6 \%)$, cystic changes $(10 \%)$, bronchiectasis (11\%), pleural effusion (5\%), and lymphadenopathy (6\%). CT findings can be non-specific, taking into account that other pathologies may present similar findings. Therefore, the use of CT is recommended to monitor changes in the disease and may serve as an aid in monitoring the progression or improvement of lung injuries in the treatment (Shi et al, 2020).

Prado and Barjud (2020) divided the period of manifestation and CT findings into the following phases: I, viral; IIA/IIB, inflammatory, and III. In the viral phase, oligosymptomatic patients or in the early stages of the pathology may not present clinical findings. In the cases of those who do, there may be focal areas with ground-glass opacities with peripheral and basal predominance. In phase IIA, CT can portray GGO with the possibility of consolidation, inverted halo, and crazy or mosaic paving. In the case of phase IIB there may be GGO and overlapping intra and interlobular septal thickening, peripheral honeycombing, and signs of pleuro-pulmonary fibrocicatrial changes. Phase III is characterized by the evolution of phase IIB with marked inflammatory changes and prominence of the vascular channels (Prado \& Bajurd, 2020).

It is considered an inverted halo signal with opacity in ground glass surrounded by consolidation in the form of a nodule or mass (Souza et al, 2002). In the case of mosaic paving, there is the GGO with thickening of the interlobular septa. Honeycombing is characterized by fibrous destruction of lung cysts, with complete loss of bronchiolar and acinar architecture (Santos et al, 2003; Souza et al, 2002).

According to Long et al (2020), CT revealed to be more sensitive than RT-PCR in the diagnosis of COVID-19, as RT-PCR can present false negatives. The study by Huang et al (2020b) reported a clinical case about a 36-year-old man with a fever, odynophagia, and fatigue for 2 days after a trip to China. The symptoms became active after 5 days of return. The tests requested were white blood cell count, neutrophils, procalcitonin, RT-PCR, and CT. The count of white blood cells (4.6x $\left.10^{9} / \mathrm{EU}\right)$, neutrophils $(53.1 \%)$, and procaciltonin showed normal levels. The sputum RT-PCR at admission showed a negative result, while the $\mathrm{CT}$ showed multiple bilateral peripheral ground-glass opacities. After 3 days a new tomography and RT-PCR were performed. The CT showed an evolution from opacities to consolidations and the RT-PCR showed a negative result. Six days after admission, the RT-PCR was repeated, this time with evidence of the suspicion of COVID-19. This case indicates the possibility of false-negative results, so the use of anamnesis with facts about recent exposures, clinical history, and symptoms related to COVID-19 (Huang et al, 2020b) were suggested. 
Due to the coverage of all audiences at COVID-19, attention to ionizing radiation is essential. Therefore, it is necessary to consider the recommendations of the Brazilian College of Radiology (CBR), in which the use of CT is indicated for cases of symptomatic and hospitalized patients, paying attention to the use of low radiation dose protocols, cleaning the room at the end of the tomographic examination and not using intravenous iodinated contrast, except for specific cases (Bertolazzi \& Melo, 2020).

The study of Araujo-Filho et al (2020) states that CT should not be used as a screening for COVID-19 for patients with these symptoms. Its use would be indicated for symptomatic and hospitalized patients, and with a specific clinical event. Since thorax CT presents non-specific findings and may be similar to other pulmonary infections, which may vary according to the stage of the disease. Therefore, it is necessary to associate the patient's clinical history, together with laboratory tests (Araujo-Filho et al, 2020).

\section{Conclusion}

The virus had a significant impact on all sectors and social groups regardless of race, color, culture, sex, nationality, social class, or any other factor. Thousands of deaths, crises, the collapse of sectors such as health, among other problems were registered. Despite all this, this pandemic leaves some positive tracks, and among those tracks is the union.

COVID-19 has proved to be a difficult enemy to fight. Its high mortality rate has devastated all continents, generating irreparable impacts. The high degree of dissemination of SARS-CoV-2 led to the need to take serious measures to combat it and revealed the importance of investments in science. Besides, the collapse caused in the health system by the current pandemic has demonstrated the importance of this sector and the need for investment in this area, as well as the relevance of joint action by health professionals.

Laboratory tests and imaging tests have proved to be of immense importance during the pandemic, with an early diagnosis being one of the weapons to prevent the transmission of SARS-CoV-2. Laboratory tests play a large role in the diagnosis of virus infection, as well as imaging tests in the diagnosis of pneumonia, but both have flaws that can be circumvented by using them together to answer questions.

The pandemic brought the population together to fight the disease and new habits were acquired. Habits that are quite beneficial. During the pandemic, some hygiene measures became a habit in the population and may remain from now on. Measures such as hand washing, use of gel alcohol, among others that have not been seen before, have become part of the daily life of all individuals. With the pandemic, we learn to think not only about ourselves, but also about the population. Finally, safety measures for general well-being have been included as a habit and perhaps the pandemic has made us better people.

Finally, it is expected that with the advances of studies of immunological and epidemiological data of COVID-19, scientists can analyze the trajectory of the SARS-CoV-2 virus until it becomes endemic. The publication of serological and imaging studies will allow a better dynamic analysis of the change in disease severity between different age groups. Thus, research in this area becomes relevant in the construction of information boards that assist in decision making.

\section{Acknowledgments}

We would like to thank you to those whose directly and indirectly contributed to this study as well as to the Public Hospital of the State of Sergipe and Emergency Hospital of Sergipe (HUSE), which made the use of the imaging test results possible. 


\section{References}

Araujo-Filho, J. A. B., Sawamura, M. V. Y., Costa, A. N., Cerri, G. G. \& Nomura, C. H. (2020). Pneumonia por COVID-19: qual o papel da imagem no diagnóstico? Jornal Brasileiro de Pneumologia, 46(2). https://doi.org/10.36416/1806-3756/e20200114

Barone, M. T. U., Harnik, S. B., de Luca, P. V, Lima, B. L. S., Wieselberg, R. J. P., Ngongo, B., Pedrosa, H. C., Pimazoni-Netto, A., Franco, D. R., Souza, M. F. M., Malta, D. C. \& Giampaoli, V. (2020). The impact of COVID-19 on people with diabetes in Brazil. Diabetes Research and Clinical Practice, 166, 108304. 10.1016/j.diabres.2020.108304.

Baroni, R. H. (2003). Radiografia de tórax ou tomografia? Einsten, 1, 43-44.

Bertolazzi, P. \& Melo, H. J. F. (2020). A importância da Tomografia Computadorizada no diagnóstico da COVID-19/The importance of Computed Tomography in diagnosis of COVID-19. Arquivos Médicos dos Hospitais e da Faculdade de Ciências Médicas da Santa Casa de São Paulo, 65:e11,1-4. https://doi.org/10.26432/1809-3019.2020.65.011

Borghesi A. \& Maroldi, R. (2020a). COVID-19 outbreak in Italy: experimental chest X-ray scoring system for quantifying and monitoring disease progression. Radiol Med, 125(5), 509-513. https://doi.org/10.1007/s11547-020-01200-3

Borghesi, A., Zigliani, A., Masciullo, R., Golemi, S., Maculotti, P., Farina, D. \& Maroldi, R. (2020b). Radiographic severity index in COVID-19 pneumonia: relationship to age and sex in 783 Italian patients. Radiol Med, 125(5), 461-464. https://doi.org/10.1007/s11547-020-01202-1

Casanova, J. L. \& Su, H. C. (2020). COVID Human Genetic Effort, A Global Effort to Define the Human Genetics of Protective Immunity to SARS-CoV-2 Infection. Cell, 181(6), 1194-1199. 10.1016/j.cell.2020.05.016.

Cellina, M., Orsi, M., Toluian, T., Valenti Pittino, C. \& Oliva, G. (2020). False negative chest X-Rays in patients affected by COVID-19 pneumonia and corresponding chest CT findings. Radiography (Lond), 26(3), e189-e194. 10.1016/j.radi.2020.04.017.

Chate, R. C. (2003). Radiografia de tórax: ainda é útil? Einsten, 1, 42-43.

Chen, T., Wu, D., Chen, H., Yan, W., Yang, D., Chen, G., Ma, K., Xu, D., Yu, h., Wang, H., Wang, T., Guo, W., Chen, J., Ding, C., Zhang, X., Huanf, J., Han, M., Li, S., Lu, X., Zhao, J. \& Li, S. (2020). Clinical characteristics of 113 deceased patients with coronavirus disease 2019: retrospective study. BMJ, 368. https://doi.org/10.1136/bmj.m1091

Elicker, B., Pereira, C. A. C., Webb, R. \& Leslie, K. O. (2008). Padrões tomográficos das doenças intersticiais pulmonares difusas com correlação clínica e patológica. J Bras pneumol, 34(9), 715-744. http://dx.doi.org/10.1590/S1806-37132008000900013

Estevão, A. (2020). COVID -19. Acta Radiológica Portuguesa, 32(1), 5-6.

Foust, A. M., Phillips, G. S., Chu, W. C., Daltro, P., Das, K. M., Garcia-Peña, P., Kilbonr, T., Winant, A. J., \& Lee, E. Y. (2020). International Expert Consensus Statement on Chest Imaging in Pediatric COVID-19 Patient Management: Imaging Findings, Imaging Study Reporting and Imaging Study Recommendations. Radiology: Cardiothoracic Imaging, 2(2), e200214. https://doi.org/10.1148/ryct.2020200214

Gordon, L., Nowik, P., Kesheh, S. M., Lidegran, M. \& Diaz, S. (2020). Diagnosis of foreign body aspiration with ultralow-dose CT using a tin filter: a comparison study. Emerg Radio.l, 27(4), 399-404. https://doi.org/10.1007/s10140-020-01764-7

Huang, C., Wang, Y., Li, X., Ren, L., Zhao, J., Hu, Y., Zhang, L., Fan, G., Xu, J., Gu, X., Cheng, Z., Yu, T., Xia, J., Wei, Y., Wu, W., Xie, X., Yin, W., Li, H., Liu, M., Xiao, Y., Gao, H., Guo, L., Xie, J., Wang, G., Jiang, R., gAO, z., jIN, q., Wang, J. \& Cao, B. (2020). Clinical features of patients infected with 2019 novel coronavirus in Wuhan, China. Lancet, 395(10223), 497-506. 10.1016/S0140-6736(20)30183-5.

Huang, P., Liu, T., Huang, L., Liu, H., Lei, M., Xu, W., Chen, J. \& Liu, Bo. (2020). Use of Chest CT in Combination with Negative RT-PCR Assay for the 2019 Novel Coronavirus but High Clinical Suspicion. Radiology. 295(1), 22-23. 10.1148/radiol.2020200330.

Long, C., Xu, H., Shen, Q., Zhang, X., Fan, B., Wang, C., Zeng, B., Li, Z., Li, X. \& Li, H. (2020). Diagnosis of the Coronavirus disease (COVID-19): RTPCR or CT? Eur J Radiol, 126:108961. 10.1016/j.ejrad.2020.108961

Neto, A. G. S., Santos, A. F., Santos, J. R., Alves, L. L., Ramos, A. C. S., Santana, A. A. F., Santos, I. D. D., Gaspar, L. M. A. C. (2021). COVID-19: Metodologias de diagnóstico. Research, Society and Development, 10(5). http://dx.doi.org/10.33448/rsd-v10i5.15114

Organização Pan-Americana de Saúde (Brasil) (OPAS/OMS) (2020). Folha informativa - COVID-19: (doença causada pelo novo coronavírus). https://www.paho.org/bra/index.php?option=com_content\&view=article\&id=6101:covid 19\&Itemid=875

Peck, K. R. (2020). Early diagnosis and rapid isolation: response to COVID-19 outbreak in Korea. Clinical Microbiology and Infection, 26(7), 805-807. 10.1016/j.cmi.2020.04.025.

Prado, G. L. M. \& Barjud, M.B. (2020). Radiologia em COVID 19: Fisiopatologia e aspectos da imagem nas diferentes fases clínicas da doença. Revista da FAESF , 4, 11-15. Retrieved from https://www.faesfpi.com.br/revista/index.php/faesf/article/view/109

Rubin, G. D., Ryerson, C. J., Haramati, L. B., Sverzellati, N., Kanne, J. P., Raoof, S., Schluger, N. W., Volpi, A., Yim, J-J., Martin, I. B. K., Anderson, D. J., Kong, C., Altes, T., Bush, A., Desai, S. R., Goldin, O., Goo, J. M., Humbert, M., Inouse, Y., Kauczor, H-U., Luo, F., Mazone, P. J., Prokop, M., Remy-Jardin, M., Richeldi, L., Schaefer-Prokop, C. M., Tomiyama, N., Wells, A. U. \& Leung, A. N. (2020). The Role of Chest Imaging in Patient Management during the COVID-19 Pandemic: A Multinational Consensus Statement from the Fleischner Society. Radiology, 296(1), 172-180. 10.1148/radiol.2020201365

Santos, M. L. O., Marchiori, E., Vianna, a. d., Souza Jr, A. S. \& Moraes, H. P. (2003). Opacidades em vidro fosco nas doenças pulmonares difusas: correlação da tomografia computadorizada de alta resolução com a anatomopatologia. Radiol Bras., 36(6). https://doi.org/10.1590/S0100-39842003000600003 
Research, Society and Development, v. 10, n. 6, e44110615936, 2021

(CC BY 4.0) | ISSN 2525-3409 | DOI: http://dx.doi.org/10.33448/rsd-v10i6.15936

Shi, H., Han, X., Jiang, N, Cao, Y., Alwalid, O., Gu, J., Fan, Y. \& Zheng, C. (2020). Radiological findings from 81 patients with COVID-19 pneumonia in Wuhan, China: a descriptive study. The Lancet Infectious Diseases, 20(4), 425-434. DOI:https://doi.org/10.1016/S1473-3099(20)30086-4

Souza Jr, A. S., Neto, C. A., Jasinovodolinsky, D., Marchiori, E., Kavakama, J., et al. (2002). Terminologia para a descrição de Tomografia Computadorizada do Tórax: Sugestões iniciais para um consenso brasileiro. Radiol Bras., 35(2), 125-128. https://doi.org/10.1590/S0100-39842002000200016

Toussie, A., Voutsinas, N., Finkelstein, M., Cedillo, M. A., Manna, S., Maron, S. Z., Jacobi., A., Chung, M., Bernheim, A., Eber, C., Concepcion, J., Fayad, Z. A. \& Gupta, S. (2020). Clinical and Chest Radiography Features determine patient outcomes in young and middle-aged adults with COVID-19. Radiologia, 297(1), 201754. https://doi.org/10.1148/radiol.2020201754

Vardavas, C. I. \& Nikitara, K. (2020). COVID-19 and smoking: A systematic review of the evidence. Tobacco Induced Diseases, 18:20. 10.18332/tid/119324.

Wang, M., Cao, R., Zhang, L., Yang, X., Liu, J., Xu, M., Shi, Z., Hu, Z., Zhong, W. \& Xiao, G. (2020). Remdesivir and chloroquine effectively inhibit the recently emerged novel coronavirus (2019-nCoV) in vitro. Cell research, 30, 269-271.

World Health Organization. (2020, January 9). WHO statement regarding cluster of pneumonia cases in Wuhan, China. Retrieved from https://www.who.int/china/news/detail/09-01-2020-who-statement-regarding-cluster-of-pneumonia-cases-in-wuhan-china

World Health Organization. (2020, May 8). Painel da Doença de Coronavírus da OMS (COVID-19). Retrieved from https://covid19.who.int/

Wu, D., Wu, T., Liu, Q. \& Yang, Z. (2020). The SARS-CoV-2 outbreak: What we know. International Journal of Infectious Diseases, 94, 44-48. 10.1016/j.ijid.2020.03.004.

Zhang, J-J., Dong, X., Cao, Y-Y., Yuan, Y-D., Yang, Y-B., Yan, Y-Q., Akdis, C. A. \& Gao, Y-D. (2020). Clinical characteristics of 140 patients infected with SARS-CoV-2 in Wuhan, China. Allergy, 75(7), 1730-1741. 10.1111/all.14238.

Zheng, Z., Yao, Z., Wu, K. \& Zheng, J. (2020). The diagnosis of pandemic coronavirus pneumonia: A review of radiology examination and laboratory test. Journal of Clinical Virology, (128), 104396. 10.1016/j.jcv.2020.104396.

Zhou, F., Yu, T., Du, R., Fan, G., Liu, Y., Liu, Z., Xiang, J., Wang, Y., Song, B., Gu, X., Guan, L., Wei, Y., Li, H., Wu, X., Xu, J., Tu, S., Zhang, Y., Chen, H. \& Cao, B. (2020). Clinical course and risk factors for mortality of adult inpatients with COVID-19 in Wuhan, China: a retrospective cohort study. Lancet, 395(10229), 1054-1062. 10.1016/S0140-6736(20)30566-3. 